\title{
Forecasting the Migration Processes Impact on the Regional Socio-Economic Situation By Means of Cognitive Modelling
}

\author{
Oleg Yu. Patlasov, b*, Oleg N. Luchko ${ }^{\mathrm{b}}$ \\ and Svetlana Kh. Mukhametdinovab \\ ${ }^{a}$ K.G. Razumovsky Moscow State University \\ of Technologies and Management \\ 63 Pushkina Str., Omsk, 644010, Russia \\ ${ }^{b}$ Omsk Humanitarian Academy \\ $2 a$ 4th Cheluskintsev Str., Omsk, 644105, Russia
}

The research problem consists in the need to resolve the contradiction between the increasing number of migrants in the recipient region, affecting the tension of the socio-economic situation and the lack of a scientifically grounded system for the effective management of incoming migration flows through the example of the Omsk Region.

The purpose of the study is to develop a system for effective management of migration processes based on the analysis and forecasting of the development of the socio-economic situation in the region by means of cognitive modelling.

The authors used the following research methods: questionnaires, expert assessment and cognitive modelling.

In the course of the study, based on an analysis of the results of the questionnaire and expert assessment, the authors identified the control factors that have the most significant impact on the level of tension of the socio-economic situation from the incoming migration flows, and created a cognitive model.

A series of simulation experiments was carried out on the developed model, which made it possible to predict changes in the target factor - the level of tension in the socio-economic situation, as a generalized characteristic reflecting the presence of contradictions in the interests of the local population and migrants, depending on the degree of influence on the controlling factors.

The proposals on the effective management of the tension of the socio-economic situation are formulated taking into account the influence of incoming migration flows. The results

(C) Siberian Federal University. All rights reserved

* Corresponding author E-mail address: opatlasov@mail.ru

ORCID: 0000-0003-2015-1474 (Patlasov); 0000-0001-8476-8954 (Luchko); 0000-0002-3063-3269 (Mukhametdinova) This work is licensed under a Creative Commons Attribution-NonCommercial 4.0 International License (CC BY-NC 4.0). 
of the study can be used in the analysis and forecasting of the tension of the socio-economic situation depending on the incoming migration flows in recipient countries or regions.

Keywords: migration processes, level of tension of the socio-economic situation, incoming migration flows, cognitive modelling.

Research area: economics.

Citation: Patlasov, O. Yu., Luchko, O.N., Mukhametdinova, S. Kh. (2019). Forecasting the migration processes impact on the regional socio-economic situation by means of cognitive modelling. J. Sib. Fed. Univ. Humanit. Soc. Sci., 12(12), 2277-2289. DOI: 10.17516/1997$1370-0522$.

\section{Introduction}

The processes of globalization and economic integration, geopolitical instability, aggravated differentiation of living standards and the presence of demographic imbalance in the developed, developing and poor countries lead to a rapid increase in migration flows that often lead to aggravation of contradictions between the interests of the local population and migrants, to the growth of socio-economic tension in recipient countries and regions.

A number of research works are devoted to the study of various aspects of migration processes. The article presents an analysis of the impact of migration processes both on the intellectual potential of labour exporting countries and on factors of the economic growth through remittances to a homeland (King, Mata-Codesal, Vullnetari, 2013).

A subject of the study is one of the most relevant problems of the modern international labour market - a "brain drain" or the outflow of the most qualified personnel from countries with developing economies, which results in a decrease in intellectual potential and worsening a socio-economic situation in donor countries (Söhn, 2016).

The article examines the impact of the migration of parents on future generations based on a comparative analysis of the achievements of European Turks and their compatriots, who remained at their native country, in the socio-economic and educational spheres of life (Guveli, 2016).

N.V. Akumova's study is devoted to the analysis of the features of labour migration in modern Russia in the context of overall migration (Akumova, 2013). There is also a comprehensive analysis of the process of formation of the international labour market, which is carried out through intercountry movement of people, as well as through the merger of national labour markets and capital without their physical movement based on the use of information and communication technologies (Patlasov, 2002). 
It should be noted that the migration of parents with a low level of human capital can have a significant impact on the educational aspirations and educational path of their children. Consequently, the objectively existing relationship between labour and educational migrations actualizes the need to invest in the education of family members and children, in particular, in host countries. In addition, high competition in the labour market of economically developed countries often stimulates labour migrants to systematically retrain and improve their skills (Böhme, 2015).

Fred Dervin analyses the trends in Chinese education policy, which, on the one hand, is increasing the export of Chinese education by inviting Chinese teachers abroad, opening branches of Chinese universities abroad, including the creation of large campuses such as, for example, the one in Malaysia, and, on the other hand, the number of Chinese people studying abroad is constantly increasing. The last statement is clearly illustrated by the following statistics: the number of Chinese students reaches $14 \%$ of all foreign students in the world (Dervin, 2015).

Based on the conceptual basis of Blumer's theory of symbolic interaction, a study by Australian scientists showed that the motivation of international students to engage in intercultural connectivity is associated not only with their desire to respect and recognize intellectual, cultural and linguistic abilities and differences, but also their aspirations for employment (Ly Thi Tran, Lien Pham, 2015).

The study (Aparicio Fenoll, Kuehn, 2017) analyses the problems of adaptation of senior students of secondary schools, colleges and universities in the host country, which are associated with family migration.

In the study "Compulsory Schooling Laws and Migration Across European Countries", based on the information from 31 European countries on compulsory education reforms, scientists checked whether increasing the length of compulsory schooling influences migration across European countries where labour mobility is almost unlimited. It is proved that an additional year of compulsory education reduces the number of people who migrate in a given year by $9 \%$ (Van de Werfhorst, 2018).

The study (Vieluf, 2016) analyses the impact on the educational achievements of children of migrants in recipient countries based on the degree of benevolence of their migration policy.

Competition in the market of educational services corresponds to the ideology of the Bologna process, which also involves overcoming national resistance, unifying the European qualification and the general labour market, as well as expanding employment opportunities (Berlinguer, 2016). 
Researchers draw attention to the need for the state policy regarding students and migrant workers through the use of expatriate community resources (Chikanda, Crush, Walton-Roberts, 2016).

The issue of a cyclical nature of migrants is considered as a key aspect of global migration (Ribas-Mateos, 2016).

A whole series of research works is devoted to the peculiarities of commuting in various countries. Thus, a foreign analysis of labour and educational migration with neighbouring countries was of particular interest to us. For example, the causes and consequences of the temporality of international mobility, temporary forms of Ukrainian migration are described in the work of Agata Gorny and Marta Kindler (Górny, Kindler, 2016). The work (Li, 2016) described in detail the concept of a "New Generation of Migrant Workers" from China.

Australia is becoming the preferred destination for Hispanic students, and this student mobility forms the basis for strengthening bilateral trade relations between Australia and major Latin American states (Calderon, 2016).

The work "Migrations, Entrepreneurship and Development: Critical Questions" investigates the issue of whether migrant entrepreneurs are more opportunistic than local people. It is proved that migrants are not super-entrepreneurs, although migration has a positive impact on the development process, and a hypothesis that return migration can bring valuable entrepreneurial skills to developing countries is not verified (Naudé, Siegel, Marchand, 2017).

The article (Luchko, Patlasov, Mukhametdinova, 2017) is devoted to the analysis of vector educational migration, as a component of migration processes, and forecasting their further development in the Omsk Region by means of cognitive modelling (Luchko, Patlasov, Mukhametdinova, 2017).

However, there is a lack of works devoted to a comprehensive study of the analysis of assessments of local residents and experts on the degree of influence of migrants on the socio-economic situation using cognitive modelling tools.

The aim of the study is to analyse, model and predict the impact of migration processes on the socio-economic situation in a cross-border region of Russia (through the example of the Omsk Region) based on the methodology of cognitive modelling.

The hypothesis of the study is that the application of the methodology of cognitive modelling to analyse the impact of incoming migration flows on the level of tension in the socio-economic situation in the Omsk Region will allow us to develop forecasts 
for its further development and make it possible to formulate recommendations for effective management of migration flows.

\section{Methodology}

The impact of incoming migration flows on economic and social processes in a region is multidimensional and ambiguous, in this regard, a concept of the level of tension of the socio-economic situation is introduced as an integral indicator. A high level of socio-economic tension characterizes a situation, in which migration has a significant negative impact on economic and social processes. Since the factors that influence the level of tension of the socio-economic situation are interconnected and have a different nature, formalization and solution of the problem of determining the degree of their influence on the resulting factor requires adequate methods.

In this regard, the methodology of cognitive modelling proposed by R. Axelrod [20] was chosen as the methodology for solving this problem. The proposed analysis and modelling methodology provide an opportunity to solve problems that are characterized by both clear and unclear interrelated factors and take into account the influence of the external environment on the system under study, as well as to predict its development.

The methodology of cognitive analysis and modelling is based on the cognitive structuring of knowledge about the object of the study and its relations with the external environment in order to identify basic factors and cause-effect relations between them.

Questionnaire and expert assessment methods were used in order to develop cognitive models. The respondents were 116 students from the Omsk Humanitarian Academy who study under full-time and part-time undergraduate and graduate programs and are citizens of the Russian Federation. In order to carry out the expert assessment, 5 professors of the Omsk State Technical University and the Omsk Humanitarian Academy were invited.

\section{Results}

In the course of the study of the level of tension of the socio-economic situation depending on the incoming migration flows in the Omsk Region, within the framework of which a sociological study and expert assessment were carried out, the following factors were identified (Table 1).

In the course of the study, taking into account the identified factors affecting the level of tension of the socio-economic situation in the Omsk Region and the relations between them (Table 1), a cognitive model was developed (Fig. 1). 
At the next stage of the study, a matrix of the influence of factors on the level of tension of the socio-economic situation in the Omsk Region depending on incoming migration flows was created on the basis of the constructed cognitive model (Table 2).

Table 1. The main control factors affecting the level of the target factor - the tension of the socio-economic situation in the Omsk Region depending on the incoming migration flow

\begin{tabular}{|c|c|c|c|}
\hline No. & Types of factors & $\begin{array}{l}\text { Measurement } \\
\text { methods }\end{array}$ & Units \\
\hline \multicolumn{4}{|c|}{ Target factor } \\
\hline $\mathrm{A}(\mathrm{A})$ & $\begin{array}{l}\text { A level of tension of the socio-economic situation in the Omsk } \\
\text { Region }\end{array}$ & $\begin{array}{c}\text { Semantic } \\
\text { differential }\end{array}$ & Points \\
\hline \multicolumn{4}{|c|}{ Control factors } \\
\hline В (Б) & Migrants perform unskilled work & Expert assessments & Points \\
\hline $\mathrm{C}(\mathrm{B})$ & $\begin{array}{l}\text { Migrants contribute to the development of certain sectors of } \\
\text { the economy: trade, construction, agriculture, etc. }\end{array}$ & Expert assessments & Points \\
\hline $\mathrm{D}(\Gamma)$ & $\begin{array}{l}\text { Migrants contribute to the process of "rejuvenation" and } \\
\text { growth of the population in the region }\end{array}$ & Expert assessments & Points \\
\hline Е (Д) & $\begin{array}{l}\text { Migrants contribute to an increase in the share of the able- } \\
\text { bodied population in the region in relation to the number of } \\
\text { dependents }\end{array}$ & Expert assessments & Points \\
\hline $\mathrm{F}(\mathrm{E})$ & $\begin{array}{l}\text { Migrants intensify competition in the labour market by } \\
\text { increasing unemployment }\end{array}$ & Expert assessments & Points \\
\hline $\mathrm{G}(Ж)$ & Migrants export earned money from the region & Expert assessments & Points \\
\hline $\mathrm{H}(3)$ & Migrants increase crime and cause inter-ethnic conflicts & Expert assessments & Points \\
\hline $\mathrm{I}(И)$ & $\begin{array}{l}\text { Migrants reduce an intellectual and economic potential of the } \\
\text { region }\end{array}$ & Expert assessments & Points \\
\hline $\mathrm{J}(\mathrm{K})$ & $\begin{array}{l}\text { Migrants change the national composition of the region's } \\
\text { population }\end{array}$ & Expert assessments & Points \\
\hline
\end{tabular}

Using specially developed software for automating the process of cognitive modelling and the influence matrix, simulation experiments were carried out. In these experiments, a magnitude of the impulses affecting individual control factors changed stepwise in percentages, and a degree of influence of these changes on the target factor (the level of tension of the socio-economic situation in the Omsk region depending on incoming migration flows) was determined. For example, a $20 \%$ increase in the impulse affecting the factor $\mathrm{J}$ and a $10 \%$ increase in the impulse affecting the factors $\mathrm{F}$ and $\mathrm{H}$ lead to an increase in the influence on the target factor A by almost $20 \%$ (Fig. 2). 


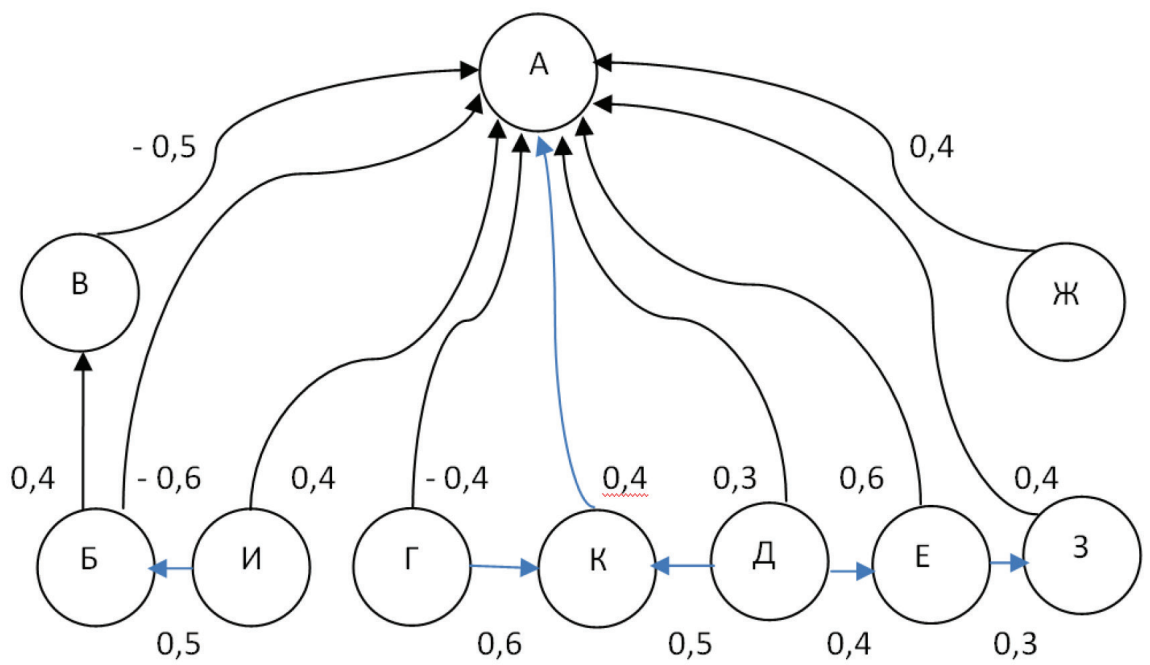

Fig. 1. A cognitive model of the level of tension of the socio-economic situation in the Omsk Region depending on incoming migration flows

Table 2. Matrix of the influence of factors on the level of tension of the socio-economic situation in the Omsk Region depending on incoming migration flows

\begin{tabular}{|c|c|c|c|c|c|c|c|c|c|c|}
\hline $\begin{array}{c}\text { Factor influence } \\
\text { matrix }\end{array}$ & $(\mathrm{A})$ & $(\mathrm{B})$ & $(\mathrm{C})$ & $(\mathrm{D})$ & $(\mathrm{E})$ & $(\mathrm{F})$ & $(\mathrm{G})$ & $(\mathrm{H})$ & $(\mathrm{I})$ & $(\mathrm{J})$ \\
\hline$(\mathrm{A})$ & 0 & -0.6 & -0.5 & -0.4 & 0.3 & 0.6 & 0.4 & 0.4 & 0.4 & 0.4 \\
\hline$(\mathrm{B})$ & 0 & 0 & 0 & 0 & 0 & 0 & 0 & 0 & 0.5 & 0 \\
\hline$(\mathrm{C})$ & 0 & 0.4 & 0 & 0 & 0 & 0 & 0 & 0 & 0 & 0 \\
\hline$(\mathrm{D})$ & 0 & 0 & 0 & 0 & 0 & 0 & 0 & 0 & 0 & 0 \\
\hline$(\mathrm{E})$ & 0 & 0 & 0 & 0 & 0 & 0 & 0 & 0 & 0 & 0 \\
\hline$(\mathrm{F})$ & 0 & 0 & 0 & 0 & 0.4 & 0 & 0 & 0 & 0 & 0 \\
\hline$(\mathrm{G})$ & 0 & 0 & 0 & 0 & 0 & 0 & 0 & 0 & 0 & 0 \\
\hline$(\mathrm{H})$ & 0 & 0 & 0 & 0 & 0 & 0.3 & 0 & 0 & 0 & 0 \\
\hline$(\mathrm{I})$ & 0 & 0.5 & 0 & 0 & 0 & 0 & 0 & 0 & 0 & 0 \\
\hline$(\mathrm{J})$ & 0 & 0 & 0 & 0.6 & 0.5 & 0 & 0 & 0 & 0 & 0 \\
\hline
\end{tabular}

It should be noted that an increase in the impulse by $20 \%$, which affects only factor J (migrants change the national composition of the region's population), leads to an increase in the impulse affecting the resulting factor by approximately $8 \%$ (Fig. 3).

Thus, the results of the simulation experiment allow us to conclude that an increase in the number of migrants that affect the national composition of the population of the recipient region, and, as a result, its socio-cultural code, is negatively perceived by 
representatives of the local population even in such a region like Omsk Region that can be considered as favourable in the context of interethnic relations.

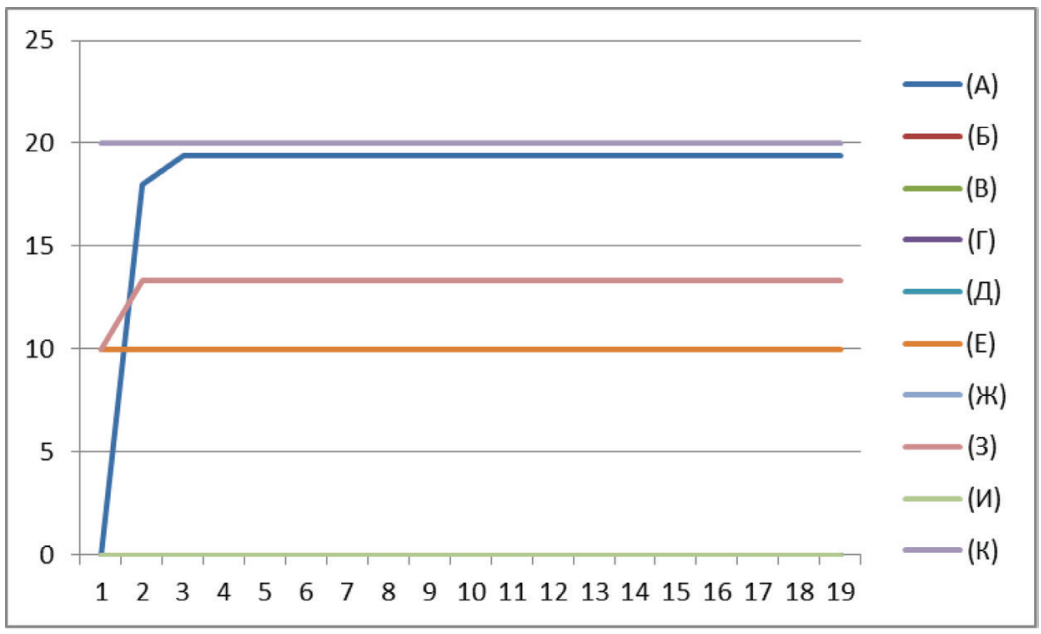

Fig. 2. The effect of the increase in impulses affecting factors $\mathrm{J}, \mathrm{F}$ and $\mathrm{H}$ on other control factors and the level of tension in the socio-economic situation in the Omsk Region depending on incoming migration flows (factor A)

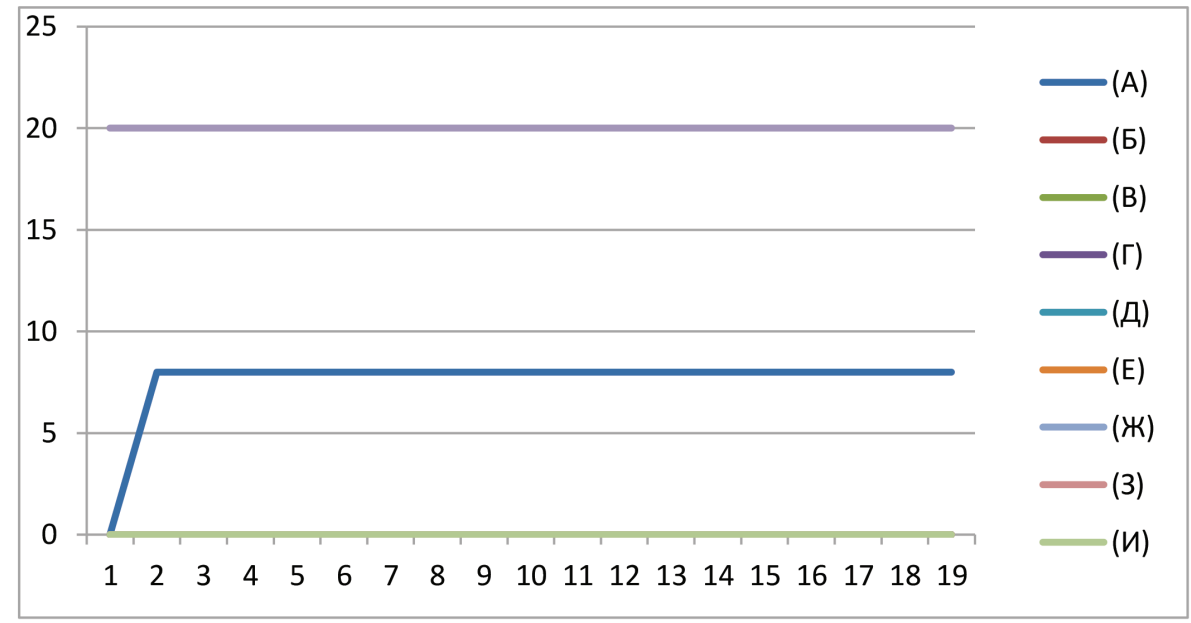

Fig. 3. The effect of the increase in the impulse affecting the factor $J$ on other control factors and the level of tension in the socio-economic situation in the Omsk Region depending on incoming migration flows (factor A)

As a result of the simulation experiment, in which the impulse affecting the factor I was increased by $20 \%$, an increase in the impulse affecting the resulting factor by almost $9 \%$ was revealed. 


\section{Conclusion}

Insufficient attention is paid to the influence of migration processes on the tension of the socio-economic situation in the regions and recipient countries. In public sources, in particular, there are no statistics on the national composition of the population in the Omsk Region, with the exception of 2002 and 2010. The migration balance is monitored, but the structure and main characteristics of migration flows, as well as their etymology, are not analysed. Despite the fact that the multinational region is characterized by stability, however, a pilot study allows us to conclude that the attitude of local residents towards migrants is ambiguous. In the more problematic, from the point of view of interethnic relations, regions and countries, there is a need for comprehensive studies aimed at identifying the dominant features of incoming migration flows, such as national composition, level of language proficiency in the country of residence and education, profession, etc. in order to develop an effective migration policy that helps to reduce the level of tension in the socio-economic situation in the region or recipient country.

The results of the study allow us to draw the following conclusions:

1. The tools of cognitive modelling allows us to solve a difficult problem of analysing and predicting the level of tension in the socio-economic situation in the Omsk Region depending on incoming migration flows.

2. To reduce the level of tension in the socio-economic situation in the Omsk Region by reducing the negative impact on the following factors:

1) $\mathrm{F}, \mathrm{H}$ and $\mathrm{J}-$ it is advisable to create a system of measures aimed at the socialization of migrants who have poor language skills of the host region and have no idea of its cultural and historical features, as well as at the professional training and retraining of migrants in accordance with the labour market conditions;

2) I - at the legislative level, it is necessary to develop a system of measures aimed at simplifying the procedure for obtaining work permits and citizenship by persons who have higher and vocational education and who have much-needed professions.

\section{References}

Akumova, N.V. (2013). Sovremennoe sostoianie trudovoi migratsii v kontekste obshchei migratsii $\mathrm{v}$ Rossii [The current state of labour migration in the context of general migration in Russia]. N.V. Akumova, G.S. Ivanov. In Pravo i obrazovanie [Law and education], (10), 114-122. Available at: https://elibrary.ru/item.asp?id= 20298428 
AparicioFenoll,A.\&Kuehn,Z.(2017).Demography,54:2181.https://doi.org/10.1007/ s13524-017-0615-x. Print ISSN0070-3370. https://link.springer.com/article/10.1007/ s13524-017-0615-X\#citeas

Axelrod, R. (1976). The Structure of Decision: Cognitive Maps of Political Elites. Princeton University Press, 405 p. Available at: https://yandex.ru/search/?text= Axelrod $\% 2$ C\%20R.\%2C\%20The $\% 20$ Structure $\% 20$ of $\% 20$ Decision $\% 3 \mathrm{~A} \% 20$ Cognitive \%20Maps\%20of\%20Political\%20Elites \&lr=66\&clid=2270455\& win $=279$

Berlinguer, L. (2016). Cross-Border Higher Education and the Services Directive: Importance, Protectionand Success. InRosa M., Sarrico C., Tavares O., Amaral A.(eds.). Cross-Border Higher Education and Quality Assurance. Issues in Higher Education. Palgrave Macmillan, London. DOI: https://doi.org/10.1057/978-1-137-59472-3_6 Available at: https://link.springer.com/chapter/10.1057/978-1-137-59472-3_6

Böhme, M.H. (2015). Migration and educational aspirations - Another channel of brain gain? In IZA Journal of Migration. December, 4, 12 DOI: 10.1186/s40176015-0036-9 Available at: https://link.springer.com/article/10.1186/s40176-0150036-9

Calderon, A. (2016). Australian-Latin American Trade Relations in Educational Services. In Kath E. (eds.) Australian-Latin American Relations. Palgrave Macmillan, New York. DOI: https://doi.org/10.1057/9781137501929_8 Available at: https://link. springer.com/chapter/10.1057/9781137501929_8

Chikanda, A., Crush, J., Walton-Roberts, M. (2016). Introduction: Disaggregating Diasporas. In Chikanda A., Crush J., Walton-Roberts M. (eds.) Diasporas, Development and Governance. Global Migration Issues, 5. Springer, Cham. DOI: https://doi.org/10.1007/978-3-319-22165-6_1 Available at: https://link.springer.com/ chapter/10.1007/978-3-319-22165-6_1

Dervin F. (2015). Introduction. In Dervin F. (eds.) Chinese Educational Migration and Student-Teacher Mobilities. Palgrave Studies on Chinese Education in a Global Perspective. Palgrave Macmillan, London. Print ISBN978-1-349-69693-2. Available at: https://link.springer.com/chapter/10.1057/9781137492913_1\#citeas

Górny, A., Kindler, M. (2016). The Temporary Nature of Ukrainian Migration: Definitions, Determinants and Consequences. In Fedyuk O., Kindler M. (eds.) Ukrainian Migration to the European Union. IMISCOE Research Series. Springer, Cham. DOI: https://doi.org/10.1007/978-3-319-41776-9_6 Available at: https://link. springer.com/chapter/10.1007/978-3-319-41776-9_6 
Guveli, A. (2016). Educational Attainment. In Intergenerational Consequences of Migration. Palgrave Macmillan, London. DOI: https://doi.org/10.1057/9781137501424_5 Available at: https://link.springer.com/chapter/10.1057/9781137501424_5

King, R., Mata-Codesal, D. \&Vullnetari, J. (2013). Migration, Development, Gender and the 'Black Box' of Remittances: Comparative Findings from Albania and Ecuador. In Comparative Migration Studies. January 2013, 1(1), 69-96. DOI: https://doi.org/10.5117/CMS2013.1.KING

Li, P. (2016). Social Attitudes, Behaviours, and the Significance of Social Governance Among New-Generation Migrant Workers. In: Li P. (eds.) Great Changes and Social Governance in Contemporary China. China Insights. Springer, Berlin, Heidelberg. DOI: https://doi.org/10.1007/978-3-662-45734-4_4 Available at: https://link.springer. com/chapter/10.1007/978-3-662-45734-4_4

Luchko, O.N., Patlasov, O. Yu., Mukhametdinova, S. Kh. (2017). Instrumetarii kognitivnogo modelirovaniia $\mathrm{v}$ analize vektornoi obrazovatel'noi migratsii [The tools of cognitive modeling in the analysis of vector educational migration]. In Bulletin of the Novosibirsk State Pedagogical University, 7(6), 225-241. Available at: http://vestnik.nspu.ru/journal/2017-6

Ly Thi Tran \& Lien Pham (2015). International students in transnational mobility: intercultural connectedness with domestic and international peers, institutions and the wider community, 560-581. Published online: 20 Aug 2015. DOI: https://doi.org/10.10 80/03057925.2015.1057479

Patlasov, O. Yu. (2002). Marketing-menedzhment rynka truda [Marketing management of the labour market]. Tomsk. Publishing house of the Tomsk state University, 640 p. Available at: https://elibrary.ru/item.asp?id=24494212

Ribas-Mateos, N. (2016). Thinking Circularity and Gender Transversality in Contemporary Migration. In: Solé C., Parella S., Martí T., Nita S. (eds.) Impact of CircularMigrationonHuman, PoliticalandCivilRights. UnitedNations UniversitySeries on Regionalism, 12. Springer, Cham. DOI https://doi.org/10.1007/978-3-319-288963_6 Available at: https://link.springer.com/chapter/10.1007/978-3-319-28896-3_6

Söhn, Janina (2016). Back to School in a New Country? The Educational Participation of Adult Immigrants in a Life-Course Perspective. In Journal of International Migration and Integration, February 2016, 17(1), 193-214. DOI: 10.1007/ s11577-012-0157-6

Van de Werfhorst, H.G. \& Heath, A. Eur J Population (2018). Springer pp 1-32. Netherlands. DOI: https://doi.org/10.1007/s10680-018-9484-2. Print ISSN0168-6577. Available at: https://link.springer.com/article/10.1007/s10680-018-9484-2 
Vieluf, S. (2016). Ethnicity and Migration. In Kuger S., Klieme E., Jude N., Kaplan D. (eds.) Assessing Contexts of Learning. Methodology of Educational Measurement and Assessment. Springer, Cham. Print ISBN978-3-319-45356-9 Available at: https://link.springer.com/chapter/10.1007/978-3-319-45357-6_6\#citeas

Wim Naudé, Melissa Siegel, Katrin Marchand (2017). Migration, entrepreneurship and development: critical questions. In IZA Journal of Migration. December 2017. DOI: 10.1186/s40176-016-0077-8 Available at: https:/link.springer.com/content/ pdf/10.1186 \%2Fs40176-016-0077-8.pdf

\title{
Прогнозирование влияния миграционных процессов на социально-экономическую ситуацию региона средствами когнитивного моделирования
}

\author{
О.Ю. Патласов ${ }^{\mathrm{a}, \tilde{\sigma}}$, О.Н. Лучко ${ }^{\tilde{\sigma}}$, \\ C.X. Мухаметдинова ${ }^{\sigma}$ \\ ${ }^{a}$ Сибирский казачий институт технологий \\ и управления (филиал) \\ Московский государственный университет технологий \\ и управления им. К.Г. Разумовского \\ Россия, 644010, Омск, ул. Пушкина, 63 \\ ${ }^{6}$ Омская гуманитарная академия \\ Россия, 644105, Омск, ул. 4-я Челюскинцев, 2 a
}

Проблема исследования состоит в необходимости разрешения противоречия между возрастающим количеством мигрантов в регионе-рециииенте, влияющим на напряженность сочиально-экономической ситуации, и отсутствием научно обоснованной системы эффективного управления входящими миграционными потоками на примере Омского региона.

Цель исследования - разработка системы эффективного управления миграционныли прочессами на основе анализа и прогнозирования развития сочиально-экономической ситуачии в регионе средствами когнитивного моделирования.

Были использованы следуюшие методы исследования: анкетирование, экспертная оценка и когнитивное моделирование.

В ходе исследования на основе анализа результатов анкетирования и экспертной оценки были выявлены управляющие факторы, оказывающие наиболее существенное влияние на уровень напряженности социально-экономической ситуации со сторонь входящих миграчионных потоков, и создана когнитивная модель.

На разработанной модели проведена серия имитационных экспериментов, позволивших спрогнозировать изменения целевого фактора - уровня напряженности 
социально-экономической ситуации как обобщенной характеристики, отражающей наличие противоречий интересов местного населения и мигрантов, в зависимости от степени воздействия на управляющие факторь.

Сформулировань предложения по эффективному управлению напряженности социально-экономической ситуачии с учетом влияния входящих миграционных потоков. Результаты исследования могут быть использованы при анализе и прогнозировании напряженности социально-экономической ситуациии в зависимости от входящих миграционных потоков в странах или регионах-рециипентах.

Ключевые слова: миграчионные процессы, уровень напряженности сочиальноэкономической ситуащии, входящие мигращионные потоки, когнитивное моделирование.

Научная спещиальность: 08.00.00 - экономические науки. 